\title{
Are Exposures to Multiple Frequencies the Key to Future Radiofrequency Research?
}

\author{
Zenon Sienkiewicz*, Carolina Calderón, Kerry A. Broom, Darren Addison, Amélie Gavard, \\ Louise Lundberg and Myron Maslanyj
}

Centre for Radiation, Chemical and Environmental Hazards, Public Health England, Chilton, United Kingdom

\section{OPEN ACCESS}

Edited by:

Mats-Olof Mattsson, Austrian Institute of Technology, Austria

Reviewed by: Theodoros Samaras, Aristotle University of Thessaloniki, Greece

Micaela Liberti,

Sapienza Università di Roma, Italy Clemens Dasenbrock,

Fraunhofer Institute for Toxicology and Experimental Medicine (FHG), Germany

*Correspondence: Zenon Sienkiewicz zenon.sienkiewicz@phe.gov.uk

Specialty section:

This article was submitted to

Radiation and Health,

a section of the journal

Frontiers in Public Health

Received: 30 August 2017 Accepted: 21 November 2017 Published: 08 December 2017

Citation:

Sienkiewicz Z, Calderón C, Broom KA, Addison D, Gavard A, Lundberg L and Maslanyj M (2017)

Are Exposures to Multiple

Frequencies the Key to Future Radiofrequency Research?

Front. Public Health 5:328. doi: 10.3389/fpubh.2017.00328
There is an extensive literature investigating possible effects of exposure to radiofrequency (RF) electromagnetic fields associated with mobile phone technologies. This has not identified any public health risks with any degree of certainty. Some epidemiological studies have observed associations between heavy users of mobile phones and some types of cancer, but animal studies do not support this association, although a few studies have reported increased tumor yields. However, there is a crucial difference between epidemiology studies and laboratory work in terms of signals investigated: most people are exposed to a complex mixture of frequencies and signals at varying intensities, whereas the majority of animal studies have been performed using a single frequency or intensity. Whether this might explain the differences in outcome will be discussed, and whether there is a need for additional laboratory investigations that reproduce more accurately realistic exposure conditions will be considered.

Keywords: multiple exposures, cancer, animal studies, radiofrequencies, review

\section{INTRODUCTION}

Around the turn of this century, concerns about mobile phone technology prompted many countries to instigate scientific research programmes into possible health effects of low-level exposure to radiofrequency (RF) electromagnetic fields. These included the Mobile Telecommunications and Health Research Programme in the UK, the German Mobile Communication Research Programme, and the Fondation Santé et Radiofréquences in France. The endpoints studied reflected public concerns at the time, and included risks of childhood and adult cancers, and effects on nervous system function. The possibility that some individuals experience hypersensitivity or non-specific symptoms in response to exposure was also considered a high priority for research. Uncertainties about possible health effects also encouraged many additional studies outside of these research programmes, including EU-funded projects, such as EMF-NET, EFHRAN, and Mobi-Kids, and this has resulted in a very extensive literature.

The results of all these studies have not identified any public health risks with any degree of certainty. Some epidemiological studies have observed associations between heavy users of mobile phones and some types of cancer, but few animal cancer or mechanistic studies provide support for this association (1-3). Associations with other diseases and endpoints are less well established.

There is a crucial difference between epidemiology studies and laboratory work in terms of signals investigated: most people are exposed to a complex mixture of frequencies and signals at varying intensities (i.e., not just the RF signals from a mobile phone but also additional RF, and lower frequency fields), whereas the majority of animal studies have been performed using a single 
frequency, and often a signal from a second (or more recently, a third) generation mobile phone. Thus, it might be argued that there is a need for additional laboratory investigations that reproduce more accurately typical exposure conditions.

This paper summarizes the typical exposures that members of the general public may experience on an everyday basis, reviews the experiments investigating carcinogenesis that have been performed with animals exposed to single or multiple RF electromagnetic fields, and considers whether there are gaps in knowledge to suggest possible future research needs. As yet, no laboratory studies investigating potential carcinogenic effects have been performed using exposures that include contributions of sources both close-to and far-from the body that may be typically experienced by a member of the public.

\section{SUMMARY OF TYPICAL PUBLIC EXPOSURES}

Members of the public are exposed to many electromagnetic fields from a large number of sources and over a large range of field intensities and frequencies. For instance, in the home, in addition to localized exposures from mobile phones, people may be exposed simultaneously to the RF signals from wireless networks (Wi-Fi), smart meters for monitoring of domestic energy usage and mobile phone base stations (downlink signals). At the same time, intermediate frequency signals are produced by appliances such as induction hobs and various lighting equipment and the electricity supply, while wireless communication devices and various electrical appliances produce electric and magnetic fields at power frequencies (but these applications are not considered further here).
Examples of exposures to RF electromagnetic fields that may occur in a typical public environment are shown in Table 1 (uniform exposure of the whole body) and Table 2 (localized exposure of the head). Comprehensive studies have been carried out by Rowley and Joyner (4) and Gajšek and colleagues (5). These authors and others have highlighted the limitations of quantifying exposure using personal exposure, which may be subject to large uncertainties including the effect of body shielding (4-6), while narrowband measurements may be less representative of average personal exposures as they tend to be performed outside and close-to base stations $(4,5,7)$.

In general, exposure levels are influenced by the power output of the device, its proximity to the body, and the duration of exposure. In addition, it is usually necessary to take into account the extent of the exposure, for instance, a local source such as a mobile phone held to the head produces a very localized exposure at the head whereas a signal from a distant mobile phone base station produces a more uniform exposure over the extent of the body. An ongoing challenge is how to translate this complex pattern of emissions into an integrated measure of exposure for use in epidemiology $(17,18)$.

Overall, a person can be exposed to a large mixture of RF and other electromagnetic fields at any one time depending on where they are and these exposures also vary in time.

\section{SUMMARY OF EPIDEMIOLOGICAL RESULTS}

A large number of epidemiological studies of mobile phone use and cancer risk have been carried out. Interest has focused on tumors of the head and neck region because these are the tissues

TABLE 1 | Examples of typical uniform radiofrequency exposures and sources likely to be encountered by a member of the public from personal dosimetry data.

\begin{tabular}{|c|c|c|c|c|c|c|c|c|c|c|}
\hline \multirow[t]{2}{*}{$\begin{array}{l}\text { Frequency } \\
\text { range, } \mathrm{MHz}\end{array}$} & \multirow[t]{2}{*}{ Source } & \multirow[t]{2}{*}{ Waveform } & \multicolumn{2}{|c|}{$\begin{array}{l}\text { Electric field } \\
\text { (RMS), } \mathrm{mV} / \mathrm{m}\end{array}$} & \multicolumn{2}{|c|}{$\begin{array}{c}\text { Equivalent Whole- } \\
\text { body specific energy } \\
\text { absorption rate (SAR), } \\
\mu \mathrm{W} / \mathrm{kg}\end{array}$} & \multicolumn{2}{|c|}{$\begin{array}{l}\text { Number } \\
\text { of samples }\end{array}$} & \multicolumn{2}{|c|}{ Reference } \\
\hline & & & Urban & Rural & Urban & Rural & Urban & Rural & Urban & Rural \\
\hline $88-108$ & $\mathrm{FM}$ & $\mathrm{FM}$ & $19-190$ & $39-55$ & $0.81-7.95$ & $1.63-2.3$ & 795 & 30 & (8) & (9) \\
\hline $174-223$ & $\mathrm{DAB} / \mathrm{TV}$ & OFDM/QPSK & $19-183$ & - & $0.40-3.75$ & - & & - & & - \\
\hline 470-830 & TV & OFDM/QPSK & $19-183$ & $43-48$ & 0.32-3.05 & $0.72-0.80$ & & 30 & & (9) \\
\hline $370-400$ & Tetrapol & FDMA & $0.00-27$ & - & $0.00-0.56$ & - & & - & & - \\
\hline $791-821$ & LTE 800 Downlink & OFDM & 0.00 & $27-34$ & 0.00 & $0.46-0.57$ & & & & \\
\hline $925-960$ & Downlink 900 & TDMA & 159-307 & $133-143$ & $3.19-4.77$ & $2.26-2.43$ & & & & \\
\hline $1,805-1,880$ & Downlink 1,800 & TDMA & $208-311$ & $136-143$ & $3.19-4.77$ & 2.09-2.19 & 20 & 30 & (9) & \\
\hline $1,880-1,900$ & DECT & TDMA & $27-43$ & 19 & $0.41-0.65$ & 0.29 & & & & \\
\hline $2,110-2,170$ & Downlink 2,100 & WCDMA & $134-152$ & 80-93 & $1.88-2.13$ & $1.12-1.30$ & & & & \\
\hline $2,620-2,690$ & LTE 2,600 Downlink & OFDM & 0.00 & 0.00 & 0.00 & 0.00 & & & & \\
\hline $2,400-2,485$ & Smart meters & DSSS, OQPSK & \multicolumn{2}{|c|}{$87-215$} & \multicolumn{2}{|c|}{$0.01-0.30^{a}$} & \multicolumn{2}{|c|}{39} & (10) & \\
\hline $2,401-2,485$ & $\mathrm{Wi}-\mathrm{Fi}$ & OFDM & $0.00-19$ & 0.00 & 0.14 & 0.00 & 20 & 30 & (9) & \\
\hline $5,150-5,872$ & Wi-Fi & OFDM & 27 & 27 & 0.35 & 0.31 & 20 & 30 & & \\
\hline
\end{tabular}

Measurements were performed with a personal exposure meter (DSP120 EME SPY (SATIMO) or ExpoM-RF) except for smart meters where measurements under controlled laboratory conditions were made with a Q-par Angus QSH12N10S horn antenna connected to an Agilent N9020A MXA signal analyzer. Equivalent whole-body specific energy absorption rate (SAR) values were calculated using conversion factors from Ref. (11) below $3 \mathrm{GHz}$ and (12) at $5 \mathrm{GHz}$. Note the latter used the NORMAN phantom scaled to a 10-year-old. OFDM, Orthogonal Frequency-Division Multiplexing; QPSK, Quadrature Phase Shift Keying; FDMA, Frequency Division Multiple Access; TDMA, Time Division Multiple Access; WCDMA, Wideband CDMA; DSSS, Direct Sequence Spread Spectrum.

a Laboratory measurements made at $1.5 \mathrm{~m}$ in direction of maximum electric field strength. Smart meter devices have a duty factor of around $1 \%$ (10); this has been included in the SAR value only. Unless specified, all measurements include duty factors. The range of values within each study is shown. 
TABLE 2 | Summary of localized radiofrequency exposures and sources likely to be encountered by a member of the public.

\begin{tabular}{|c|c|c|c|c|c|c|}
\hline $\begin{array}{l}\text { Frequency } \\
\text { range, } \mathrm{MHz}\end{array}$ & Source & $\begin{array}{l}\text { Specific energy absorption } \\
\text { rate (SAR) } 10 \mathrm{~g} \text { head, } \mathrm{mW} / \mathrm{kg}\end{array}$ & Waveform & $\begin{array}{l}\text { Number of } \\
\text { samples }\end{array}$ & Comment & Reference \\
\hline 880-915 & GSM & $268(15-557)$ & TDMA & 351 & \multirow{2}{*}{$\begin{array}{l}\text { Values have been scaled by } 0.5 \text { to account for adaptive power } \\
\text { control (typical power levels) and a further } 0.7 \text { to account for } \\
\text { Discontinuous Transmission (13) }\end{array}$} & \multirow[t]{2}{*}{ (13) } \\
\hline 1,710-1,785 & GSM & $180(14-595)$ & TDMA & 120 & & \\
\hline 1,920-1,980 & UMTS & $5(0.4-18)$ & WCDMA & 120 & $\begin{array}{l}\text { Estimated using SAR from GSM1800 and scaling it to take into } \\
\text { account differences in duty factor (1:1 versus 1:8), maximum } \\
\text { output power ( } 125 \mathrm{~mW} \text { versus } 1 \mathrm{~W} \text { ) and typical power levels } \\
\text { (1\% of maximum versus 50\%). Does not take into account } \\
\text { difference in frequency }\end{array}$ & \\
\hline 1,880-1,900 & $\begin{array}{l}\text { DECT } \\
\text { phones }\end{array}$ & $45(3-148)$ & TDMA & 120 & $\begin{array}{l}\text { Estimated using SAR from GSM1800 and scaling it to take } \\
\text { into account differences in duty factor }(1: 24) \text { and output power } \\
(0.250 \mathrm{~W})\end{array}$ & \\
\hline $2,400-2,484$ & Wi-Fi & $2(1.0-3.3)$ & OFDM & 15 & \multirow[b]{2}{*}{$\begin{array}{l}\text { Estimated using average Equivalent Isotropically Radiated Power } \\
\text { from lab measurements (14) and scaling factors for SAR modeling } \\
\text { of an inverted F-antenna in a laptop placed } 34 \mathrm{~cm} \text { from a scaled } \\
\text { 10-year-old (12). Measurements in schools suggest that duty factor } \\
\text { of laptops during classrooms is around } 0.08 \%, N=146 \text { (15), while } \\
\text { another study found a median of } 1.4 \% \text { for various environments } \\
\text { and activities, } N=179(16)\end{array}$} & \multirow[t]{2}{*}{$(12,14)$} \\
\hline $5,150-5,872$ & laptops & $2(0.4-3.8)$ & OFDM & 8 & & \\
\hline
\end{tabular}

All exposures are for handheld phones during voice calls. Values are arithmetic means and ranges of values are shown in brackets. Values do not include duty factor from typical usage but takes into account duty factor from TDMA communication systems (i.e., 1:8 for GSM and 1:24 for DECT).

GSM, Global System for Mobile communication; UMTS, Universal Mobile Telecommunications Service; DECT, Digital Enhanced Cordless Telecommunications;

TDMA, Time Division Multiple Access; WCDMA, Wideband Code Division Multiple Access; OFDM, Orthogonal Frequency-Division Multiplexing.

that are primarily exposed by the RF fields from mobile phones, but some studies have investigated other types of tumors, including leukemia, lymphoma, and malignant melanoma. Additional studies have investigated effects of occupational exposure to RF fields, or examined time-trend data for brain tumors. All these data have been extensively studied and reviewed by many expert groups, including the independent Advisory Group on Nonionizing Radiation (1), the International Agency for Research on Cancer (IARC) (2) and the Scientific Committee on Emerging and Newly Identified Health Risks (SCENIHR) (3) and only a brief summary of the overall conclusions is presented here.

Taken together, the epidemiological studies do not provide consistent evidence of a carcinogenic effect of RF exposure at levels encountered in the general population. Nevertheless, IARC concluded that there was limited evidence in humans for the carcinogenicity of RF fields, due to the positive associations observed between glioma and acoustic neuroma and exposure to RF fields from wireless phones, and overall RF fields were considered to be possibly carcinogenic to humans (2). This means that a causal link between RF fields and an increased risk of cancer was considered to be credible, but some combination of chance, bias or confounding in the data could not be ruled out with an acceptable degree of confidence.

The bulk of evidence for this decision from IARC (2) came from the INTERPHONE study and a Swedish case-control study by Hardell and colleagues. In particular, the INTERPHONE study did not observe raised risks of brain tumors, acoustic neuroma, or parotid gland tumors among regular mobile phone users, and the risk estimates did not increase with longer time since first mobile phone use. There were, however, suggestions of an increased risk of glioma at the highest exposure level (1640 h or more of cumulative phone use) and among long-term users in the most exposed areas of the brain $(19,20)$. It is possible that exposure may have caused modest risk increases in only the heaviest users of mobile phones. If correct, such increases may not be detectable in cohort studies or in the time-trend data (3). Exposure misclassification is a considerable problem in such studies, and in relation to the present discussion, exposures from other sources are rarely taken into account to any meaningful degree. Based on cohort and case-control studies published since the IARC assessment, SCENIHR concluded that the evidence for glioma had become weaker (3). However, SCENIHR acknowledged that research was still lacking in some areas, particularly for investigating long-term effects associated with mobile phone use, and recommended prospective cohort studies in adults and children as a high priority.

Overall, the evidence from epidemiology studies does not suggest that exposure to RF fields associated with mobile phone use is a significant health risk for most people. However, the possibility that increased risks may exist in the small number of very high users cannot be excluded with certainty, although these increased risks may be related to previous technology that tended to expose the tissues of the head and neck to more intense fields. The retrospective assessment of exposures from mobile phones remains an ongoing challenge given the rapidly changing technologies and changes in behavioral pattern of use.

\section{SUMMARY OF STUDIES WITH ANIMALS}

Excluding any study that may have obvious shortcomings in methodology or had insufficient or absent dosimetry, such as using an unmodified mobile phone as an exposure source (3), most recent long-term animal studies using a single frequency have reported a lack of carcinogenic effects in a variety of animal 
models, including classical long-term bioassays (Table 3), studies using transgenic and tumor-prone animals (Table 4), co-carcinogenicity studies involving combined exposure to RF fields and known carcinogens (Tables 5 and 6), and studies evaluating effects on the development of tumors after transplantation or inoculation of tumor cells (Table 7). Generally, these studies used frequencies associated with mainstream mobile technology, and assessed tumor yields using post-mortem pathology, although the studies included in Table 7 used very high frequencies (40-60 GHz) and at field strengths that caused significant increases in local tissue temperatures, which are less representative of exposures from mobile phones. All these studies were judged and selected for inclusion in the tables using quality criteria similar to those used in a systematic review of phone use and brain cancer (21). These criteria included having adequate study size, use of an appropriate exposure system, and suitable data analysis.

However, it is of interest that one study (36) reported positive results in a pilot study using transplacental administration of ethylnitrosourea (ENU) to induce mutagenicity in brain tissues. It was found that lifetime exposure to $1966 \mathrm{MHz}$ UMTS signals at a whole-body specific energy absorption rate (SAR) of up to $5 \mathrm{~W} / \mathrm{kg}$ (peak) had no effect on incidence of brain tumors, but exposure increased the incidence and multiplicity of lung carcinoma in female mice compared with animals treated with ENU alone. Significant effects were also seen on liver tumors, but these were discounted due to possible confounding caused by bacterial infection. UMTS exposure on its own had no tumorigenic effect.

These results were independently replicated using the same experimental design although the study was improved by using a larger number of exposure groups (37). Animals were exposed at a whole-body average SAR of up to $2 \mathrm{~W} / \mathrm{kg}$. Generally, the results of this second study were consistent (but not identical) with those of the pilot study, possibly indicating the inherent variability in tumor incidence with this model. Prenatal ENU treatment has been considered an ideal experimental model for the study of brain tumors in transgenic mice (46) so the absence of any increase in brain tumors in both studies is intriguing, but could be due to factors such as the dose of ENU used, the time at which it was injected, or strain-specific sensitivity. In addition, a dose-response was absent in the replicate study with no explanation offered as to why exposure at $0.4 \mathrm{~W} / \mathrm{kg}$ (but not at 0.04 or $2 \mathrm{~W} / \mathrm{kg}$ ) should have had the most consistent effect on tumor promotion.

In addition, the much-anticipated first report from the National Toxicology Program (NTP) study on the effects of RF fields

TABLE 3 | Animal studies investigating carcinogenic potential of radiofrequency fields in conventional strains.

\begin{tabular}{|c|c|c|c|c|}
\hline Endpoint & Exposure conditions & Results of exposure & Comments & Reference \\
\hline $\begin{array}{l}\text { Tumors in male and } \\
\text { female Fischer rats }\end{array}$ & $\begin{array}{l}835 \mathrm{MHz} \text { FDMA, or } 847 \mathrm{MHz} \text { CDMA; } \\
4 \mathrm{~h} / \text { day, } 5 \text { days/week for } 2 \text { years; at } \\
1.3 \pm 0.25 \mathrm{~W} / \mathrm{kg} \text { in brain, animals restrained }\end{array}$ & $\begin{array}{l}\text { No significant effects on survival, growth, } \\
\text { incidences of brain tumors or other } \\
\text { neoplasms, or on non-neoplastic lesions }\end{array}$ & $\begin{array}{l}\text { Restraint devices increased in size with } \\
\text { animals' age. Animals irradiated in early } \\
\text { morning }\end{array}$ & (22) \\
\hline $\begin{array}{l}\text { Brain tumors in male } \\
\text { and female Fischer } \\
344 \text { rats }\end{array}$ & $\begin{array}{l}\text { Iridium } 1.6 \mathrm{GHz} ; 2 \mathrm{~h} / \text { day from gd } 19 \text { until } \\
\text { postnatal day } 23 \pm 2 \text { (weaning), at } 0.16 \mathrm{~W} / \mathrm{kg} \\
\text { in brain, animals freely moving; and } 2 \mathrm{~h} / \text { day, } \\
5 \text { days/week from } 35 \text { days old until } 2 \text { years of } \\
\text { age, at } 0.16 \text { or } 1.6 \mathrm{~W} / \mathrm{kg} \text { in brain, head-only } \\
\text { exposure, animals restrained }\end{array}$ & $\begin{array}{l}\text { No significant effect on early survival, } \\
\text { weaning or growth weights, clinical signs, } \\
\text { or incidences of brain tumors or other } \\
\text { neoplasms }\end{array}$ & $\begin{array}{l}\text { Significant increase in weight in male } \\
\text { and female cage controls, and significant } \\
\text { decrease in survival of female cage controls }\end{array}$ & (23) \\
\hline $\begin{array}{l}\text { Tumors in male and } \\
\text { female Han Wistar } \\
\text { rats }\end{array}$ & $\begin{array}{l}\text { GSM } 902 \text { MHz or DCS } 1747 \mathrm{MHz} \text {; } \\
2 \text { h/day, } 5 \text { days/week for } 2 \text { years; at } 0.4 \text {, } \\
\text { 1.2, or } 3.7 \text { W/kg GSM; or } 0.4,1.3 \text { or } \\
4 \text { W/kg DCS; animals restrained }\end{array}$ & $\begin{array}{l}\text { Some incidental differences, but no } \\
\text { significant effects on health status, clinical } \\
\text { signs, food consumption, body or organ } \\
\text { weights, or mortality. No significant } \\
\text { increases in numbers of tumor-bearing } \\
\text { animals, total numbers of tumors, or in } \\
\text { any specific tumor type }\end{array}$ & $\begin{array}{l}\text { Specific energy absorption rate (SAR) of } \\
\text { GSM reduced due to large rat growth. } \\
\text { Exposure consisted of three different } \\
\text { 40-min phases emulating talking, listening, } \\
\text { and moving in environment. Highest } \\
\text { exposure below thermal threshold. Carried } \\
\text { out under good laboratory practice } \\
\text { standards }\end{array}$ & (24) \\
\hline $\begin{array}{l}\text { Tumors in male and } \\
\text { female B6C3F1 mice }\end{array}$ & $\begin{array}{l}\text { GSM } 902 \mathrm{MHz} \text { or DCS } 1747 \mathrm{MHz} \text {; } \\
2 \text { h/day, } 5 \text { days/week for } 2 \text { years; at } \\
0.4,1.3 \text {, or } 4 \mathrm{~W} / \mathrm{kg} \text {; animals restrained }\end{array}$ & $\begin{array}{l}\text { No significant effects on health status, } \\
\text { clinical signs, food consumption, body or } \\
\text { organ weights, or mortality. No significant } \\
\text { increases in numbers of tumor-bearing } \\
\text { animals, total numbers of tumors, or in } \\
\text { any specific tumor type }\end{array}$ & $\begin{array}{l}\text { Exposure consisted of three different 40-min } \\
\text { phases emulating talking, listening, and } \\
\text { moving in environment. Highest exposure } \\
\text { below thermal threshold. Incidence of all } \\
\text { tumor types in line with historical values. } \\
\text { Carried out under good laboratory practice } \\
\text { standards }\end{array}$ & (25) \\
\hline $\begin{array}{l}\text { Tumors, in female } \\
\text { SD rats }\end{array}$ & $\begin{array}{l}\text { GSM } 900 \mathrm{MHz} \text {; continuous exposure, except } \\
\text { for } 15 \mathrm{~min} / \text { day (feeding), } 4 \times 1-2 \mathrm{~h} / \text { week } \\
\text { (health check and cleaning), } 4-5 \mathrm{~h} / \text { month } \\
\text { (servicing) for up to } 3 \text { years of age; at } 0.08 \mathrm{~W} / \\
\mathrm{kg} \text { (young) to } 0.038 \mathrm{~W} / \mathrm{kg} \text { (old); group of } 12 \\
\text { animals freely moving in home cage }\end{array}$ & $\begin{array}{l}\text { No significant effects on incidence of } \\
\text { pituitary, mammary, or other tumors weight } \\
\text { gain or survival with exposures }<2 \text { years. } \\
\text { Significant reduction in median survival } \\
\text { with exposures lasting }>2 \text { years }\end{array}$ & $\begin{array}{l}\text { Modest group sizes. Effects on survival } \\
\text { modulated by time of year of birth }\end{array}$ & (26) \\
\hline
\end{tabular}

SD, Sprague-Dawley; FDMA, Frequency Division Multiple Access; TDMA, Time Division Multiple Access; GSM, Global System for Mobile communication; DCS, Digital Cellular System; gd, gestational day.

SAR values are mean whole-body averages unless indicated otherwise; significant indicates statistical significance. 
TABLE 4 | Animal studies investigating the potential of radiofrequency fields to promote tumors in tumor-prone animals.

\begin{tabular}{|c|c|c|c|c|}
\hline Endpoint & Exposure conditions & Results of exposure & Comments & Reference \\
\hline $\begin{array}{l}\text { Lymphoma in AKR/J } \\
\text { mice, analysis of blood }\end{array}$ & $\begin{array}{l}900 \mathrm{MHz} \text { GSM, } 24 \mathrm{~h} / \text { day for } \\
41 \text { weeks, at } 0.4 \mathrm{~W} / \mathrm{kg} \text {, in home } \\
\text { cage, animals freely moving }\end{array}$ & $\begin{array}{l}\text { No significant effects on survival, incidence of } \\
\text { lymphoma, blood cell counts. Significant increase } \\
\text { in weight gain }\end{array}$ & $\begin{array}{l}\text { Field turned off for } 1 \mathrm{~h} \text { twice } \\
\text { per week for cleaning, animal } \\
\text { inspection }\end{array}$ & (27) \\
\hline $\begin{array}{l}\text { Lymphoma in AKR/J } \\
\text { mice, analysis of blood }\end{array}$ & $\begin{array}{l}\text { UMTS test signal, } 1.966 \mathrm{GHz}, 24 \mathrm{~h} / \\
\text { day for } 35 \text { weeks, at } 0.4 \mathrm{~W} / \mathrm{kg} \text {, in } \\
\text { home cage, animals freely moving }\end{array}$ & $\begin{array}{l}\text { No significant effects on survival, incidence of } \\
\text { lymphoma, lymphatic infiltrations, white blood cell } \\
\text { counts, weight gain. Lower weight in cage controls } \\
\text { attributed to different feeding methods }\end{array}$ & $\begin{array}{l}\text { Field turned off for } 1 \mathrm{~h} \text { twice } \\
\text { per week for cleaning, animal } \\
\text { inspection }\end{array}$ & (28) \\
\hline $\begin{array}{l}\text { Lymphoma in Pim1 } \\
\text { transgenic mice }\end{array}$ & $\begin{array}{l}900 \mathrm{MHz} \text {, pulse width } 0.577 \mathrm{~ms} \text {, } \\
217 \mathrm{~Hz}, 1 \mathrm{~h} \text { /day for } 18 \text { months, } \\
\text { at } 0.5,1.4 \text {, or } 4 \mathrm{~W} / \mathrm{kg} \text {, animals } \\
\text { restrained }\end{array}$ & $\begin{array}{l}\text { Sporadic changes, but no consistent effects on clinical } \\
\text { signs, weight gain, incidence of lymphoma, histiocystic } \\
\text { sarcoma, or other tumors. Survival decreased in all } \\
\text { groups of males, and in females at } 0.5 \mathrm{~W} / \mathrm{kg}\end{array}$ & $\begin{array}{l}\text { Includes animals at end } \\
\text { of exposure. Significant } \\
\text { differences in cage control } \\
\text { animals. Carried out under } \\
\text { good laboratory practice } \\
\text { standards }\end{array}$ & (29) \\
\hline $\begin{array}{l}\text { Multiple tumors } \\
\text { (medulloblastoma, } \\
\text { rhabdomyosarcomas, } \\
\text { or preneoplastic } \\
\text { lesions typical of } \\
\text { basal cell carcinomas) } \\
\text { in Patched1 (Ptc1) } \\
\text { heterozygous mice }\end{array}$ & $\begin{array}{l}900 \mathrm{MHz} \text { GSM, } 2 \times 30 \mathrm{~min} / \text { day for } \\
5 \text { days, from postnatal day } 2-6 \text {, } \\
\text { at } 0.4 \mathrm{~W} / \mathrm{kg} \text {, animals restrained in } \\
\text { polystyrene jigs }\end{array}$ & $\begin{array}{l}\text { No significant decrease in survival, no significant } \\
\text { increase in incidence, onset or histology of tumors, } \\
\text { or in preneoplastic skin lesions. No effects on liver or } \\
\text { other neoplasms }\end{array}$ & $\begin{array}{l}\text { Ptc1 show peak sensitivity to } \\
\text { X-rays during early postnatal } \\
\text { life }\end{array}$ & (30) \\
\hline
\end{tabular}

GSM, Global System for Mobile communication; UMTS, Universal Mobile Telecommunications Service.

Specific energy absorption rate values are mean whole-body averages; significant indicates statistical significance.

on rodent carcinogenesis has been published online (47). This suggested that lifetime, intermittent exposure to CDMA or GSM $900 \mathrm{MHz}$ signals at a whole-body average SAR of $1.5-6 \mathrm{~W} / \mathrm{kg}$ for $18 \mathrm{~h}$ per day increased the incidence of malignant gliomas in the brain and schwannomas of the heart in male, but not female, rats. Results from other organs have not yet been reported, nor any results from the other half of the study using mice. Overall, the available results are far from conclusive, not least because many pertinent details about the study are missing from the report and concerns exist about the unexpected absence of tumors in the (single) control group. Comments made by one of the reviewers of the study which were included as an appendix in the report indicate that if the tumor incidence rate in the control group had occurred at the historical rate for those rats in that institution, then the results would not have reached statistical significance. Comprehensive analysis on this study must await full publication of the complete NTP dataset. (This study is not included in Table 3 for these reasons.)

Together, the pilot study (36) and replicate study (37) using the transplacental ENU model perhaps provide the strongest experimental evidence to suggest that long-term exposure to single RF fields may have some tumor promoting effects, but the evidence remains inadequate to make definitive conclusions. This is due in part to differences in results between the two studies, the lack of an obvious dose-response relationship (37), and unresolved questions about the potential nature of the biological interaction mechanism. Importantly, other studies using similar models have not reported comparable effects (Table 5).

Only two studies appear to have investigated the direct carcinogenic effects of combined exposure to more than one RF field (Table 8). In both studies, which come from the same research group, unrestrained animals were exposed using a reverberation chamber to $849 \mathrm{MHz}$ CDMA and $1950 \mathrm{MHz}$ WCDMA signals at a whole-body average SAR of $2 \mathrm{~W} / \mathrm{kg} /$ signal (making $4 \mathrm{~W} / \mathrm{kg}$ in total).

In one study, young rats were exposed to CDMA and WCDMA signals for $45 \mathrm{~min} /$ day, 5 day/week for a year (48). Animals were exposed alternately in the morning or afternoon. No significant effects on weight or on spontaneous tumor rates were found, and post-mortem analysis did not show any significant pathological differences that could be related to exposure. In addition, analysis of blood and urine did not reveal any significant field-related effects except for a significant increase in mean corpuscular hemoglobin level, and alkaline phosphatase in males; and a significant decrease in total bilirubin, and lactate dehydrogenase in females.

In the other study, young AKR/J mice (which express the ecotropic retrovirus $\mathrm{AKV}$ in all tissues and spontaneously develop lymphoma) were exposed to combined CDMA and WCDMA signals for $45 \mathrm{~min} /$ day, 5 day/week for 42 weeks (49). Compared to sham-exposed controls, exposure had no significant effect on weight, survival time, or incidence of lymphoma. The latter was assessed by histopathological analysis of the thymus. Blood counts remained unaffected by exposure and there were no consistent effects on metastatic infiltration in the spleen or other organs (changes in infiltration seen in the brain were attributed to other factors, not exposure). In addition, but not related to carcinogenesis, the same research group has also reported that combined exposure to $848 \mathrm{MHz}$ CDMA and $1950 \mathrm{MHz}$ WCDMA signals have no teratological effect on ICR mice exposed throughout gestation (50); no effect on testicular function in SD rats exposed for 12 weeks (51); no effect on immune functions in male SD rats exposed for 8 weeks (52); nor any effect on endocrine function in male and female SD rats exposed for 4 or 8 weeks (53). Animals in these four studies were exposed for 45 or $90 \mathrm{~min} /$ day for 5 days/ week at a total whole-body average SAR of $4 \mathrm{~W} / \mathrm{kg}$. 
TABLE 5 | Animal studies investigating co-carcinogenic effects of radiofrequency fields following transplacental ENU administration.

\begin{tabular}{|c|c|c|c|c|}
\hline Endpoint & Exposure conditions & Results of exposure & Comments & Reference \\
\hline $\begin{array}{l}\text { CNS tumors in male } \\
\text { and female Fischer } \\
344 \text { rats }\end{array}$ & $\begin{array}{l}836.55 \mathrm{MHz} \text { FM talk signal; } 2 \mathrm{~h} / \text { day from dg } 19 \\
\text { until postnatal day } 21 \text {, animals freely moving; and } \\
2 \mathrm{~h} / \text { day, 4/days week, from day } 31 \text { for } 2 \text { years, } \\
\text { at } 1-1.2 \mathrm{~W} / \mathrm{kg} \text { in brain, animals restrained; and/ } \\
\text { or single maternal intravenous injection of ENU } \\
\text { (4 mg/kg on dg 18) }\end{array}$ & $\begin{array}{l}\text { No significant effects on survival, number, incidence, } \\
\text { or any tumor type }\end{array}$ & $\begin{array}{l}\text { Effects with ENU. No } \\
\text { effect on spontaneous } \\
\text { tumors }\end{array}$ & (31) \\
\hline $\begin{array}{l}\text { CNS tumors in SD } \\
\text { rats }\end{array}$ & $\begin{array}{l}860 \mathrm{MHz} \text { pulsed or continuous wave MiRS } \\
\text { signal, } 6 \mathrm{~h} / \text { day, } 5 \text { days/week from } 53 \text { days old to } \\
24 \text { months, at } 1 \mathrm{~W} / \mathrm{kg} \text { in brain, animals restrained, } \\
\text { and/or single maternal intravenous injection of } \\
\text { ENU }(2,5 \text {, or } 10 \mathrm{mg} / \mathrm{kg} \text { on dg } 15)\end{array}$ & No significant effects on brain or spinal cord tumors & $\begin{array}{l}\text { Carried out under good } \\
\text { laboratory practice } \\
\text { standards }\end{array}$ & $(32)$ \\
\hline $\begin{array}{l}\text { CNS tumors in } \\
\text { Fischer } 344 \text { rats }\end{array}$ & $\begin{array}{l}1.439 \mathrm{GHz} \text { TDMA signal, } 90 \text { min/day, } 5 \text { days/ } \\
\text { week from } 5 \text { weeks of age, for } 104 \text { weeks at } 0.67 \\
\text { or } 2 \mathrm{~W} / \mathrm{kg} \text { in brain, head-only exposure, animals } \\
\text { restrained, and/or single maternal intravenous } \\
\text { injection of ENU ( } 4 \mathrm{mg} / \mathrm{kg} \text { on dg 18) }\end{array}$ & $\begin{array}{l}\text { No significant effects on CNS tumors, pituitary } \\
\text { tumors significantly reduced in males at } 2 \mathrm{~W} / \mathrm{kg} \text {, } \\
\text { no significant effect on growth or survival }\end{array}$ & $\begin{array}{l}\text { Carried out under good } \\
\text { laboratory practice } \\
\text { standards }\end{array}$ & (33) \\
\hline $\begin{array}{l}\text { CNS tumors in SD } \\
\text { rats, assessed every } \\
30 \text { days } 171 \text { to } \\
325 \text { days }\end{array}$ & $\begin{array}{l}860 \mathrm{MHz} \text { pulsed, MiRS signal, } 6 \mathrm{~h} / \text { day, } 5 \text { days/ } \\
\text { week (excluding holidays) from } 50 \text { days old, at } \\
1 \mathrm{~W} / \mathrm{kg} \text { in brain, animals restrained, and/or single } \\
\text { maternal intravenous injection of ENU ( } 6.2 \text { or } \\
10 \mathrm{mg} / \mathrm{kg} \text { on dg 15) }\end{array}$ & $\begin{array}{l}\text { No significant effects on incidence, malignancy } \\
\text { multiplicity or latency of spinal cord or spinal nerve } \\
\text { tumors, cranial nerve tumors, or brain tumors }\end{array}$ & & $(34)$ \\
\hline $\begin{array}{l}\text { CNS tumors in } \\
\text { Fischer } 344 \text { rats }\end{array}$ & $\begin{array}{l}1.95 \mathrm{GHz} \text { WCDMA signal, } 90 \mathrm{~min} / \text { day, } 5 \text { days/ } \\
\text { week from } 5 \text { weeks of age, for } 104 \text { weeks at } 0.67 \\
\text { or } 2 \mathrm{~W} / \mathrm{kg} \text { in brain, head-only exposure, animals } \\
\text { restrained, and/or single maternal intravenous } \\
\text { injection of ENU ( } 4 \mathrm{mg} / \mathrm{kg} \text { on dg 18) }\end{array}$ & $\begin{array}{l}\text { No significant effects on CNS tumors, skin fibromas } \\
\text { and large granular lymphocytic leukemia significantly } \\
\text { reduced in males exposed at } 2 \mathrm{~W} / \mathrm{kg} \text {, no significant } \\
\text { effect on growth or survival }\end{array}$ & $\begin{array}{l}\text { Carried out under good } \\
\text { laboratory practice } \\
\text { standards }\end{array}$ & (35) \\
\hline $\begin{array}{l}\text { Tumors in B6C3F1 } \\
\text { female mice }\end{array}$ & $\begin{array}{l}1.966 \mathrm{GHz} \text { UMTS, } 20 \mathrm{~h} / \text { day for up to } 24 \text { months } \\
\text { starting on dg 6, at } 4.8 \text { or } 48 \mathrm{~W} / \mathrm{m} \text {, peak specific } \\
\text { energy absorption rate (SAR) calculated at } 5 \mathrm{~W} / \mathrm{kg} \\
\text { and/or single maternal intraperitoneal injection of } \\
\text { ENU ( } 40 \mathrm{mg} / \mathrm{kg} \text { ) on dg } 14 \text { in low exposure group, } \\
\text { animals freely moving }\end{array}$ & $\begin{array}{l}\text { No significant effects with UMTS alone. Incidence, } \\
\text { malignancy, and multiplicity of lung carcinomas } \\
\text { significantly increased in ENU + UMTS, and } \\
\text { numbers of lung metastases (non-significantly) } \\
\text { doubled. Effects on liver tumors discounted due to } \\
\text { Helicobacter infection }\end{array}$ & $\begin{array}{l}\text { Highest SAR did not } \\
\text { induce increase in } \\
\text { temperature }\end{array}$ & $(36)$ \\
\hline $\begin{array}{l}\text { Tumors in B6C3F1 } \\
\text { female mice }\end{array}$ & $\begin{array}{l}1.966 \mathrm{GHz} \text { UMTS, } 23.5 \mathrm{~h} / \text { day for } 72 \text { weeks } \\
\text { starting on dg } 6 \text {, at } 0.04,0.4 \text {, or } 2 \mathrm{~W} / \mathrm{kg} \text { and } \\
\text { single maternal ip injection of ENU }(40 \mathrm{mg} / \mathrm{kg}) \text { on } \\
\text { dg } 14 \text {, animals freely moving }\end{array}$ & $\begin{array}{l}\text { Significant increases in lung adenomas and liver } \\
\text { carcinomas at all SARs, lung carcinoma, and } \\
\text { lymphomas at } 0.4 \mathrm{~W} / \mathrm{kg} \text {. No dose-response. No } \\
\text { increase in any tumor in brain, kidney, spleen }\end{array}$ & $\begin{array}{l}\text { No UMTS-only group. } \\
\text { No Helicobacter } \\
\text { infection at } 1 \text { year }\end{array}$ & $(37)$ \\
\hline
\end{tabular}

CNS, central nervous system; ENU, N-ethyl-N-nitrosourea; SD, Sprague-Dawley; MiRS, Motorola integrated Radio Services; TDMA, Time Division Multiple Access; WCDMA,

Wideband Code Division Multiple Access; UMTS, Universal Mobile Telecommunications Service; dg, gestational day; ip, intraperitoneal.

$S A R$ values are mean whole-body averages, unless indicated otherwise; significant indicates statistical significance.

Another research group has examined the effects of a simultaneous exposure to $900 \mathrm{MHz}$ and $2.45 \mathrm{GHz}$ fields on endpoints that are relevant to carcinogenesis but did not investigate malignant pathology. In these studies (not included in Table 8), restrained male rats were exposed at up to $0.2 \mathrm{~W} / \mathrm{kg}$ in a GTEM cell, and SARs were estimated using numerical phantoms. In the first study, it was reported that single or simultaneous exposure had no effect on cellular morphology and apoptosis in eight tissues, including the brain, muscle, and testicles (54). In the second study, effects on cellular stress responses were investigated in the cerebral cortex and cerebellum (55). Some significant changes were seen in heat shock protein and caspase-3 expression, but simultaneous exposure did not result in any consistent effect compared to either single frequency alone. The average whole-body SAR of the combined signal was comparable, if slightly less than the value for the single frequencies (approximately $0.03-0.08$ and $0.05-0.09 \mathrm{~W} / \mathrm{kg}$ respectively). The authors concluded that simultaneous exposure to two low-level signals at different frequencies did not result in any additive effects or changes that were greater than those of each signal separately.

In summary, high-quality experimental studies with animals (and mechanistic in vitro studies) should be informative and help to decide whether RF fields can have a significant carcinogenic effect. The available evidence from animal studies does not suggest long-term, low-level exposure to either a single or two RF fields can have a significant influence on carcinogenesis. The majority of well-performed studies using a single frequency provide strong evidence for an absence of effects, particularly for tumors of the brain and nervous system, with no consistent changes reported on weight gain, survival, or increases in any tumor type or non-plastic lesion seen. In addition, no consistent dose-response trends have been reported in any study. Two studies using the same mouse model, however, report longterm exposure at whole-body SARs as low as $0.04 \mathrm{~W} / \mathrm{kg}$ may increase the potential of a chemical mutagen to cause tumors, 
TABLE 6 | Animal studies investigating co-carcinogenic effects of radiofrequency fields with other carcinogenic agents.

\begin{tabular}{|c|c|c|c|c|}
\hline Endpoint & Exposure conditions & Results of exposure & Comments & Reference \\
\hline $\begin{array}{l}\text { Mammary tumors } \\
\text { in female SD rats, } \\
\text { following initiation with } \\
\text { DMBA }\end{array}$ & $\begin{array}{l}\text { GSM } 900 \text { MHz; continuous exposure, except for } \\
10-20 \text { min/day (feeding), } 3 \times 1-2 \mathrm{~h} / \text { week (cleaning), } \\
3-4 \mathrm{~h} / \text { week for tumor palpation, } 4-5 \mathrm{~h} / \mathrm{month} \\
\text { (servicing) for up to } 334 \text { days; at } 0.03-0.13 \mathrm{~W} / \mathrm{kg} \\
\text { (young) to } 0.01-0.06 \mathrm{~W} / \mathrm{kg} \text { (old); group of } 12 \text { animals } \\
\text { freely moving, and DMBA (50 mg/kg) by gavage }\end{array}$ & $\begin{array}{l}\text { Overall, no significant effects on } \\
\text { incidence or latency of benign } \\
\text { or malignant tumors. Incidence } \\
\text { of malignant tumors significantly } \\
\text { reduced only in first experiment }\end{array}$ & $\begin{array}{l}\text { Three experiments in total. Exposures } \\
\text { began in evening after DMBA } \\
\text { treatment. Animals sacrificed when } \\
\text { tumors were } 1-2 \mathrm{~cm} \text { in diameter }\end{array}$ & (38) \\
\hline $\begin{array}{l}\text { Skin tumors in male } \\
\text { ICR mice, following } \\
\text { initiation with DMBA, } \\
\text { assessed at sacrifice } \\
\text { after } 20 \text { weeks }\end{array}$ & $\begin{array}{l}848.5 \text { or } 1762 \mathrm{MHz} \text { CDMA, } 2 \times 45 \mathrm{~min} / \text { day, } 5 \text { days/ } \\
\text { week for } 19 \text { weeks, at } 0.4 \mathrm{~W} / \mathrm{kg} \text {, animals freely } \\
\text { moving, and DMBA ( } 100 \mu \mathrm{\mu g} \text { per } 100 \mu \mathrm{l}) \text { painted } \\
\text { on dorsal skin }\end{array}$ & $\begin{array}{l}\text { No skin tumors, and no effects } \\
\text { on epidermis }\end{array}$ & $\begin{array}{l}\text { Exposures began } 7 \text { days after DMBA } \\
\text { treatment, each } 45 \text {-min exposure } \\
\text { separated by } 15 \text { min. Significant } \\
\text { effects seen with phorbol acetate }\end{array}$ & (39) \\
\hline $\begin{array}{l}\text { Tumors in female } \\
\text { Wistar rats, with } \mathrm{MX} \\
\text { throughout study }\end{array}$ & $\begin{array}{l}900 \mathrm{MHz} \text { GSM, } 2 \text { h/day, } 5 \text { days/week for } 104 \text { weeks, } \\
\text { at } 0.3 \text { or } 0.9 \text { W/kg, animals freely moving, and MX } \\
\text { (1.7 mg/kg in drinking water) }\end{array}$ & $\begin{array}{l}\text { No significant effects on organ- } \\
\text { specific incidence of any tumor } \\
\text { type, effect in merged vascular } \\
\text { tumors attributed to chance }\end{array}$ & & $(40)$ \\
\hline $\begin{array}{l}\text { Mammary tumors } \\
\text { in female SD rats, } \\
\text { following single initiation } \\
\text { with DMBA }\end{array}$ & $\begin{array}{l}900 \mathrm{MHz} \text { GSM, } 4 \mathrm{~h} / \text { day, } 5 \text { days/week for } 26 \text { weeks } \\
\text { at } 0.44,1.33 \text { or } 4 \mathrm{~W} / \mathrm{kg} \text {, animals restrained, and } \\
\text { DMBA ( } 35 \mathrm{mg} / \mathrm{kg} \text { ) by gavage }\end{array}$ & $\begin{array}{l}\text { No significant effects on benign } \\
\text { or malignant mammary tumors }\end{array}$ & $\begin{array}{l}\text { Exposures began } 1 \text { day after DMBA } \\
\text { treatment. Significant differences in } \\
\text { weight, tumor incidence, and latency } \\
\text { in cage controls }\end{array}$ & $(41)$ \\
\hline $\begin{array}{l}\text { Mammary tumors } \\
\text { in female SD rats, } \\
\text { following initiation with } \\
\text { DMBA }\end{array}$ & $\begin{array}{l}902 \mathrm{MHz} \text { GSM, } 4 \text { h/day, } 5 \text { days/week for } 186 \text { days } \\
\text { at } 0.44,1.33 \text { or } 4 \mathrm{~W} / \mathrm{kg} \text {, animals restrained, and } \\
\text { DMBA ( } 17 \mathrm{mg} / \mathrm{kg} \text { ) by gavage }\end{array}$ & $\begin{array}{l}\text { Sporadic significant differences } \\
\text { observed, but no dose-related } \\
\text { trends. Overall, no differences } \\
\text { attributed to exposure }\end{array}$ & $\begin{array}{l}\text { Exposures began } 1 \text { day after DMBA } \\
\text { treatment. Significant differences in } \\
\text { tumor incidence and malignancy in } \\
\text { cage controls carried out under good } \\
\text { laboratory practice standards }\end{array}$ & $(42)$ \\
\hline
\end{tabular}

SD, Sprague-Dawley; CDMA, Code Division Multiple Access; GSM, Global System for Mobile communication; MX, 3-chloro-4-(dichloromethyl)-5-hydroxy-2(5H) furanone:

DMBA, 7,12-dimethylbenz(a)anthracene.

Specific energy absorption rate values are mean whole-body averages, unless indicated otherwise; significant indicates statistical significance.

TABLE 7 | Animal studies investigating effects of radiofrequency fields on implanted tumor cells.

\begin{tabular}{|c|c|c|c|c|}
\hline Endpoint & Exposure conditions & Results of exposure & Comments & Reference \\
\hline $\begin{array}{l}\text { B16 F10 melanoma cells injected sc } \\
\text { into Swiss Webster mice }\end{array}$ & $\begin{array}{l}61.22 \mathrm{GHz}, 15 \mathrm{~min} / \text { day for } 5 \text { days } \\
\text { at } 133 \mathrm{~W} / \mathrm{m} \text { to the head, animals } \\
\text { restrained }\end{array}$ & $\begin{array}{l}\text { Significantly reduced tumor growth with } \\
\text { exposures starting on day } 5 \text { after injection, } \\
\text { no significant effects with exposures } \\
\text { starting on day } 1 \text { or } 10\end{array}$ & $\begin{array}{l}\text { Effect blocked by naloxone } \\
\text { hydrobromide ( } 1 \mathrm{mg} / \mathrm{kg}) \text {. } \\
\text { Maximum temperature } \\
\text { rise of around } 1^{\circ} \mathrm{C} \text { at tip } \\
\text { of nose }\end{array}$ & (43) \\
\hline $\begin{array}{l}\text { B16 F10 melanoma cells injected sc } \\
\text { into SKH1 hairless mice, and/or CPA } \\
\text { (30 or } 20 \mathrm{mg} / \mathrm{kg}) \text { injected ip, on days } \\
4-8\end{array}$ & $\begin{array}{l}42.2 \mathrm{GHz}, 60 \mathrm{~Hz} \text { modulation, } 30 \mathrm{~min} / \\
\text { day for } 5 \text { days at } 365 \mathrm{~W} / \mathrm{m} \text { (peak) } \\
\text { to the nose [peak specific energy } \\
\text { absorption rate (SAR) of } 730 \mathrm{~W} / \mathrm{kg} \text { ], } \\
\text { animals restrained }\end{array}$ & $\begin{array}{l}\text { Dose-dependent reduction in tumor } \\
\text { growth with CPA, no additional effects with } \\
\text { exposure on days } 4-8 \text { post-inoculation, nor } \\
\text { with exposure before and/or after CPA }\end{array}$ & $\begin{array}{l}\text { Temperature rise of } 1.5^{\circ} \mathrm{C} \\
\text { on the nose }\end{array}$ & (44) \\
\hline $\begin{array}{l}\text { B16 F10 melanoma cells injected } \\
\text { intravenously in female C57BL/ } 6 \text { mice } \\
\text { on day } 2 \text { post-exposure, and/or CPA } \\
\text { (150 mg/kg) ip; numbers of metastatic } \\
\text { lung colonies counted after } 2 \text { weeks }\end{array}$ & $\begin{array}{l}42.2 \mathrm{GHz}, 60 \mathrm{~Hz} \text { modulation, } 30 \mathrm{~min} \\
\text { at } 365 \mathrm{~W} / \mathrm{m} \text { (peak) to the nose } \\
\text { (peak SAR of } 730 \mathrm{~W} / \mathrm{kg} \text { ), animals } \\
\text { anesthetized }\end{array}$ & $\begin{array}{l}\text { CPA alone significantly increased } \\
\text { metastases, RF alone or RF + CPA } \\
\text { significantly decreased metastases, } \\
\text { RF + CPA significantly increased activity of } \\
\text { natural killer cells }\end{array}$ & $\begin{array}{l}\text { Temperature rise of } 1.5^{\circ} \mathrm{C} \\
\text { on the nose }\end{array}$ & (45) \\
\hline
\end{tabular}

sc, subcutaneous; ip, intraperitoneal; CPA, cyclophosphamide.

Significant indicates statistical significance.

and preliminary results from an NTP study suggest increased risks for at least two tumor types after lifetime exposure of male rats to $900 \mathrm{MHz}$ at a few $\mathrm{W} / \mathrm{kg}$. There are far fewer studies with animals simultaneously exposed to more than one frequency, and the available evidence is in line with the data from the single frequency studies, and no consistent effects of exposure have been seen.

\section{FUTURE RESEARCH NEEDS}

Members of the public are exposed to a complex and variable mixture of RF (and lower) frequency electromagnetic fields and exposures critically depend on the distance from the source, together with the emitted power and duty factor. Mobile phones, which tend to be the major source of RF exposure, have adaptive 
TABLE 8 | Animal studies investigating carcinogenic potential of simultaneous exposure to two different RF frequencies.

\begin{tabular}{|c|c|c|c|c|}
\hline Endpoint & Exposure conditions & Results of exposure & Comments & Reference \\
\hline $\begin{array}{l}\text { Weight gain, survival, in SD rats, urinalysis, } \\
\text { hematology, blood biochemistry after } \\
\text { exposure }\end{array}$ & $\begin{array}{l}849 \mathrm{MHz} \text { CDMA and } 1.95 \mathrm{GHz} \text { WCDMA, } \\
45 \mathrm{~min} / \text { day, } 5 \text { days/week for } 1 \text { year, at } 2 \mathrm{~W} / \\
\text { kg per signal, animals freely moving, am or } \\
\text { pm alternately }\end{array}$ & $\begin{array}{l}\text { No significant effects except significant increase in } \\
\text { mean corpuscular hemoglobin level and alkaline } \\
\text { phosphatase in males, and significant decrease in } \\
\text { total bilirubin and lactate dehydrogenase in females }\end{array}$ & & (48) \\
\hline $\begin{array}{l}\text { Weight gain, survival, lymphoma incidence } \\
\text { in AKR/J mice, blood biochemistry after } \\
26 \text { weeks of exposure, metastatic } \\
\text { infiltration by IHC }\end{array}$ & $\begin{array}{l}849 \mathrm{MHz} \text { CDMA and } 1.95 \mathrm{GHz} \text { WCDMA, } \\
45 \mathrm{~min} / \text { day, } 5 \text { days/week for } 42 \text { weeks, at } \\
2 \mathrm{~W} / \mathrm{kg} \text { per signal, animals freely moving, } \\
\text { am or pm alternately }\end{array}$ & $\begin{array}{l}\text { No significant effects. Significant decrease in } \\
\text { metastatic infiltration in brain of males, increase in } \\
\text { females, not due to exposure }\end{array}$ & & (49) \\
\hline
\end{tabular}

SD, Sprague-Dawley; CDMA, Code Division Multiple Access; WCDMA, Wideband CDMA; IHC, immunohistochemistry.

Specific energy absorption rate values are mean whole-body averages, significant indicates statistical significance.

power control to adjust their output power to preserve battery life, which further complicates personal exposure assessment. By contrast, animal studies have used at most two RF signals, and usually at constant power, although some studies have increased their relevance to the human situation by using a signal that mimics the output of mobile phone during a conversation. Overall, the fields used in animal experiments are not typical of all the fields that are experienced by mobile phone users in everyday life, although generally represent the dominant near-field exposure.

Therefore, it might be argued that further research with animals would be needed in order to clarify the relevance of combined, multiple fields to cancer risk under realistic exposure conditions. However, such a programme of work is considered unfeasible at this time, and is not recommended as a high priority for the following reasons.

First, neither the animal or human data suggest that substantial increased risks are associated with exposure to RF fields under any particular circumstances. The animal data have investigated a variety of models and none has produced unequivocal evidence of increased risks, even with long-term and intense exposures, and using models that are considered more sensitive to reveal effects. Similarly, some of the human data are suggestive of increased risks, but overall fail to provide conclusive proof of harm. Both lines of research have different strengths and weaknesses, but generally they tend to complement and inform one another, and reinforce their findings. Thus, there is no overwhelming suggestion from existing observational or experimental studies that exposure of animals to multiple fields is likely to yield more positive, fieldrelated results (although if such studies were performed and they produced negative effects, that data would still be of interest and provide additional inputs to risk assessment of these fields).

Another reason for this recommendation is a lack of plausible interaction mechanism whereby two or more RF signals could interact to produce a more than additive effect. Presently, the absorption of power leading to tissue heating is the main mechanism whereby RF fields have an effect on living tissues (stimulation of excitable tissues by induced electric fields at up to $10 \mathrm{MHz}$ is the other established mechanism). In the case of heating, the combined effect of exposure is the sum of the absorbed powers (56). Different frequencies would have different penetration into the body leading to different patterns of absorption, but the time-averaged thermal burden is considered to be the sum of the individual heating components. Thus, it is not possible to envisage exposure to multiple weak fields as having a greater overall effect than a single field at that combined intensity. Of course, this does not deny that if exposures induce hyperthermia then circulatory and other changes will occur (57) and if exposure is sufficiently intense or prolonged this can result in thermal damage to tissues, but even in this context, hyperthermia from RF fields is not considered to be carcinogenic (58) so even intense exposures should not increase the risk of cancer.

In addition, although it has sometimes been suggested that specific frequencies, modulations, or pulse shapes can be more effective at producing biological effects than continuous wave or sinusoidal fields $(59,60)$ such a proposition has not been firmly established and the results of the animal cancer studies (as described in Tables 3-8) do not suggest the existence of any field- or modulation-related effects, and exposure to any particular signal never consistently resulted in any field-related effects. Furthermore, attempts to identify such a non-thermal mechanism that could operate at all RF frequencies and realistic field intensities have not proved successful [see 3 (61),]. A systematic approach to the effects literature identified five credible non-thermal mechanisms (62). These included iron-ionmediated reactions, and the radical pair mechanism. However, selective microthermal heating was considered the most plausible mechanism, although it lacked experimental verification of the microthermal properties of cells. In another detailed review of potential mechanisms, it was concluded that the dominant mechanism at RF frequencies was dielectric heating (63). Most other putative mechanisms were considered implausible as a means for independent energy deposition because they would result in temperature rises that would overwhelm any other biological response. Resonant molecular or sub-molecular vibrational modes were also excluded because they would be too heavily damped, while other mechanisms involved energy that would be far weaker than the thermal background. It was also concluded that field strengths that are greatly in excess of those that would cause dielectric heating would be necessary to interact directly with charges or dipoles. However, it was suggested that non-linear processes such as rectification could transduce frequency-modulated signals into a more biologically relevant frequency range where physiological systems operate. In a direct test of this suggestion, a doubly resonant cavity was used to search for non-linear energy conversion in a wide range of biological samples that included cancer cells and slices of mouse tissues (64). 
Samples were exposed to a continuous wave field at the resonant frequency of the cavity and monitored for generation of the second harmonic. The absence of any consistent second harmonic indicated a lack of support for the hypothesis, since second harmonic generation was considered to be a necessary and sufficient condition for demodulation. Beyond a gradual change from effects based on induced electric fields to ones based on heating with increasing frequency, the possibility of explicit effects at specific frequencies are also absent in scientifically based guidelines limiting human exposure to RF fields $(56,65)$. Overall, while it cannot be completely dismissed, it seems increasingly less likely that there could be some previously unidentified non-thermal mechanism that only operates with exposure to some specific combinations of fields or modulations.

In the absence of a clear hypothesis to guide the choice of the particular frequencies to be investigated, nor any specific information on the important exposure parameters, such as intensity, duration, or pattern of exposure, it is reasonable to adopt a pragmatic approach and use the two or three fields that dominate personal exposure, perhaps in terms of maximum incident power density or time-averaged whole-body or local SAR, but even this approach has no absolute guarantee of success. It would be extremely expensive and unrealistically time-consuming to try all the various combinations of fields to which people are commonly exposed in order to discover the most effective combination. Such an approach is far better suited to high-throughput in vitro techniques (66) and not long-term studies with animals.

Finally, it would be absolutely essential to decide on an appropriate biological model to use in these studies. The use of different mouse models for investigating (ionizing) radiationinduced cancers has been reviewed (67). It was suggested that the ideal mouse model possesses a low spontaneous background frequency of the desired malignancy, has a short latency period, avoids the co-development of cancers at alternative sites, and produces nearly identical tumors to the corresponding human cancer in terms of onset, progression, and underlying pathology (67). But it is acknowledged that a perfect model may not exist, so the best available model would have to be used depending on the type of cancer being investigated. One possible mouse to use to investigate brain cancer might be the Patched $1\left(\mathrm{Ptc}^{+/-}\right)$knockout model. This is a well-established model for carcinogenesis, and was previously used to investigate effects of RF fields (30). One practical advantage of this model is that since sensitivity to $\mathrm{X}$-irradiation is known to be greatest in early postnatal life in this model, exposure to multiple RF fields could be restricted to the period before weaning, and the tumor yield measured and characterized in response to exposure. Other suitable models would have to be identified for other types of cancer. As with previous animal studies, these studies would not be trying to replicate use of mobile phones per se, but to provide information about qualitative effects of exposure to RF fields. Mouse models cannot generally provide reliable estimates of risk in humans due to inherent differences in anatomy and body size, and in metabolism and lifespan. Differences also exist in DNA repair capacity, and in the etiology of tumor development (68). Overall, based on this analysis, the likelihood that exposure to multiple, low-level RF exposures would have unexpected consequences and significantly increased the risk of any type of cancer is considered to be low, but the possibility cannot be completely excluded. Nevertheless, it would be prudent to initiate such studies with animals only once an interaction mechanism had been better identified, and at least some of the more pertinent exposure parameters were known.

\section{CONCLUSION}

Most long-term animal studies investigating the carcinogenic potential of RF fields have used a single frequency, usually at one intensity, which is in contrast to the variable combination of fields and intensities that may be experienced by people in the everyday environment. These studies suggest that longterm exposure of animals is unlikely to affect the initiation or development of any type of cancer, but this possibility cannot be dismissed completely as a few studies have reported field-related changes.

Thus, it might seem sensible to consider the need for additional animal studies using exposures that are more typical of the multiple sources that are likely to be encountered by a member of the public (as defined in Tables 1 and 2), especially given the widespread and increasing use of wireless and other technologies. However, as exposures to multiple weak fields are only known to have no greater effect than a single field at the combined intensity, such research should only be undertaken if it is considered plausible that there could be an as yet unknown biological interaction mechanism whereby multiple fields could pose an increased carcinogenic hazard. Knowledge of this mechanism might also help to guide selection of the fields to be tested, as otherwise there is little explicit information to suggest which frequencies to use beyond the dominant exposure from use of a mobile phone. In the absence of a possible mechanism and uncertainty about the signals, additional work with animals exposed to multiple RFs is considered unlikely to yield valuable information about fielddependent effects (although data showing no exposure-related effects can still be useful for risk assessment). Therefore, animal studies investigating the carcinogenic potential of exposure to multiple RF frequencies should not be given a high priority for research at this time.

\section{AUTHOR CONTRIBUTIONS}

ZS conceived the work, and with KAB, AG, and LL contributed equally to the interpretation and drafting on the biology. CC, DA, and MM contributed equally in the acquisition of the measurement data and drafted the sections on measurements. All authors approved the final version and agreed to be accountable for all aspects of the work.

\section{FUNDING}

Work was performed as part of our regular employment with Public Health England. 


\section{REFERENCES}

1. AGNIR. Health Effects from Radiofrequency Electromagnetic fields. Report of the independent Advisory Group on Non-ionising Radiation. Docs HPA, RCE20 (2012). Available from: https://www.gov.uk/government/publications/ radiofrequency-electromagnetic-fields-health-effects

2. IARC. Non-ionizing Radiation Part 2: Radiofrequency Electromagnetic Fields. Monograph Series. (Vol. 102). Lyon: International Agency for Research on Cancer (2013).

3. SCENIHR. Opinion on Potential Health Effects of Exposure to Electromagnetic Fields. Scientific Committee on Emerging and Newly Identified Health Risks. Brussels, European Commission (2015). Available from: http://ec.europa.eu/ health/scientific_committees/emerging/docs/scenihr_o_041.pdf

4. Rowley JT, Joyner KH. Comparative international analysis of radiofrequency exposure surveys of mobile communication radio base stations. J Expo Sci Environ Epidemiol (2012) 22:304-15. doi:10.1038/jes.2012.13

5. Gajšek P, Ravazzani P, Wiart J, Grellier J, Samaras T, Thuróczy G. Electromagnetic field exposure assessment in Europe radiofrequency fields (10 MHz-6 GHz). J Expo Sci Environ Epidemiol (2015) 25:37-44. doi:10.1038/ jes. 2013.40

6. Neubauer G, Cecil S, Giczi W, Petric B, Preiner P, Fröhlich J, et al. The association between exposure determined by radiofrequency personal exposimeters and human exposure: a simulation study. Bioelectromagnetics (2010) 31:535-45. doi:10.1002/bem.20587

7. Röösli M. Epidemiology of Electromagnetic Fields. Boca Raton, FL: CRC Press (2014). 368 p.

8. Joseph W, Frei P, Röösli M, Thuróczy G, Gajsek P, Trcek T, et al. Comparison of personal radio frequency electromagnetic field exposure in different urban areas across Europe. Environ Res (2010) 110:658-63. doi:10.1016/j. envres.2010.06.009

9. Sagar S, Struchen B, Finta V, Eeftens M, Röösli M. Use of portable exposimeters to monitor radiofrequency electromagnetic field exposure in the everyday environment. Environ Res (2016) 150:289-98. doi:10.1016/j. envres.2016.06.020

10. Peyman A, Addison D, Mee T, Goiceanu C, Maslanyj M, Mann S. Exposure to electromagnetic fields from smart utility meters in GB; Part I) laboratory measurements. Bioelectromagnetics (2017) 38:280-94. doi:10.1002/bem.22044

11. Dimbylow PJ. Fine resolution calculations of SAR in the human body for frequencies up to $3 \mathrm{GHz}$. Phys Med Biol (2002) 47:2835-46. doi:10.1088/00319155/47/16/301

12. Findlay RP, Dimbylow PJ. SAR in a child voxel phantom from exposure to wireless computer networks (Wi-Fi). Phys Med Biol (2010) 55:N405-11. doi:10.1088/0031-9155/55/15/N01

13. Cardis E, Varsier N, Bowman JD, Deltour I, Figuerola J, Mann S, et al. Estimation of RF energy absorbed in the brain from mobile phones in the Interphone Study. Occup Environ Med (2011) 68:686-93. doi:10.1136/oemed2011-100065

14. Peyman A, Khalid M, Calderon C, Addison D, Mee T, Maslanyj M, et al. Assessment of exposure to electromagnetic fields from wireless computer networks (wi-fi) in schools; results of laboratory measurements. Health Phys (2011) 100:594-612. doi:10.1097/HP.0b013e318200e203

15. Khalid M, Mee T, Peyman A, Addison D, Calderon C, Maslanyj M, et al. Exposure to radio frequency electromagnetic fields from wireless computer networks: duty factors of Wi-Fi devices operating in schools. Prog Biophys Mol Biol (2011) 107:412-20. doi:10.1016/j.pbiomolbio.2011.08.004

16. Joseph W, Pareit D, Vermeeren G, Naudts D, Verloock L, Marten L, et al. Determination of the duty cycle of WLAN for realistic radio frequency electromagnetic field exposure assessment. Prog Biophys Mol Biol (2013) 111:30-6. doi:10.1016/j.pbiomolbio.2012.10.002

17. Roser K, Schoeni A, Bürgi A, Röösli M. Development of an RF-EMF exposure surrogate for epidemiologic research. Int J Environ Res Public Health (2015) 12:5634-56. doi:10.3390/ijerph120505634

18. Roser K, Schoeni A, Struchen B, Zahner M, Eeftens M, Fröhlich J, et al. Personal radiofrequency electromagnetic field exposure measurements in Swiss adolescents. Environ Int (2017) 99:303-14. doi:10.1016/j.envint. 2016.12.008

19. Cardis E, Deltour I, Vrijheid M, Evrard AS, Moissonnier M, Amstrong B, et al. Acoustic neuroma risk in relation to mobile telephone use: results of the INTERPHONE international case-control study. Cancer Epidemiol (2011) 35:453-64. doi:10.1016/j.canep.2011.05.012

20. Cardis E, Armstrong BK, Bowman JD, Giles GG, Hours M, Krewski D, et al. Risk of brain tumours in relation to estimated RF dose from mobile phones: results from five Interphone countries. Occup Environ Med (2011) 68:631-40. doi:10.1136/oemed-2011-100155

21. RepacholiMH,LerchlA, RöösliM,SienkiewiczZ, Auvinen A, BreckenkampJ, et al. Systematic review of wireless phone use and brain cancer and other head tumors. Bioelectromagnetics (2010) 33:187-206. doi:10.1002/ bem. 20716

22. La Regina M, Moros EG, Pickard WF, Straube WL, Baty J, Roti Roti JL. The effect of chronic exposure to $835.62 \mathrm{MHz}$ FDMA or 847.74 MHz CDMA radiofrequency radiation on the incidence of spontaneous tumors in rats. Radiat Res (2007) 160:143-51. doi:10.1667/RR3028

23. Anderson LE, Sheen DM, Wilson BW, Grumbein SL, Creim JA, Sasser LB. Two-year chronic bioassay study of rats exposed to a $1.6 \mathrm{GHz}$ radiofrequency signal. Radiat Res (2004) 162:201-10. doi:10.1667/RR3208

24. Smith P, Kuster N, Ebert S, Chevalier HJ. GSM and DCS wireless communication signals: combined chronic toxicity/carcinogenicity study in the Wistar rat. Radiat Res (2007) 168:480-92. doi:10.1667/RR0680.1

25. Tillmann T, Ernst H, Ebert S, Kuster N, Behnke W, Rittinghausen S, et al. Carcinogenicity study of GSM and DCS wireless communication signals in B6C3F1 mice. Bioelectromagnetics (2007) 28:173-87. doi:10.1002/ bem. 20283

26. Bartsch H, Küpper H, Scheurlen U, Deerberg F, Seebald E, Dietz K, et al. Effect of chronic exposure to a GSM-like signal (mobile phone) on survival of female Sprague-Dawley rats: modulatory effects by month of birth and possibly stage of the solar cycle. Neuro Endocrinol Lett (2010) 31:457-73

27. Sommer AM, Streckert J, Bitz AK, Hansen VW, Lerchl A. No effects of GSMmodulated $900 \mathrm{MHz}$ electromagnetic fields on survival rate and spontaneous development of lymphoma in female AKR/J mice. BMC Cancer (2004) 4:77. doi:10.1186/1471-2407-4-77

28. Sommer AM, Bitz AK, Streckert J, Hansen VW, Lerchl A. Lymphoma development in mice chronically exposed to UMTS-modulated radiofrequency electromagnetic fields. Radiat Res (2007) 168:72-80. doi:10.1667/ RR0857.1

29. Oberto G, Rolfo K, Yu P, Carbonatto M, Peano S, Kuster N, et al. Carcinogenicity study of $217 \mathrm{~Hz}$ pulsed $900 \mathrm{MHz}$ electromagnetic fields in Pim1 transgenic mice. Radiat Res (2007) 168:316-26. doi:10.1667/rr0425.1

30. Saran A, Pazzaglia S, Mancuso M, Rebessi S, Di Majo V, Tanori M, et al. Effects of exposure of newborn patched1 heterozygous mice to GSM, 900 MHz. Radiat Res (2007) 168:733-40. doi:10.1667/RR1065R1.1

31. Adey WR, Byus CV, Cain CD, Higgins RJ, Jones RA, Kean CJ, et al. Spontaneous and nitrosourea-induced primary tumors of the central nervous system in Fischer 344 rats exposed to frequency-modulated microwave fields. Cancer Res (2000) 60:1857-63.

32. Zook BC, Simmens SJ. The effects of $860 \mathrm{MHz}$ radiofrequency radiation on the induction or promotion of brain tumors and other neoplasms in rats. Radiat Res (2001) 155:572-83. doi:10.1667/0033-7587(2001)155[0572: TEOMRR]2.0.CO;2

33. Shirai T, Kawabe M, Ichihara T, Fujiwara O, Taki M, Watanabe S, et al. Chronic exposure to a $1.439 \mathrm{GHz}$ electromagnetic field used for cellular phones does not promote N-ethylnitrosourea induced central nervous system tumors in F344 rats. Bioelectromagnetics (2005) 26:59-68. doi:10.1002/ bem.20079

34. Zook BC, Simmens SJ. The effects of pulsed $860 \mathrm{MHz}$ radiofrequency radiation on the promotion of neurogenic tumors in rats. Radiat Res (2006) 165:608-15. doi:10.1667/RR3551.1

35. Shirai T, Ichihara T, Wake K, Watanabe S, Yamanaka Y, Kawabe M, et al. Lack of promoting effects of chronic exposure to $1.95-\mathrm{GHz}$ W-CDMA signals for IMT-2000 cellular system on development of N-ethylnitrosourea-induced central nervous system tumors in F344 rats. Bioelectromagnetics (2007) 28:562-72. doi:10.1002/bem.20324

36. Tillmann T, Ernst H, Streckert J, Zhou Y, Taugner F, Hansen V, et al. Indication of cocarcinogenic potential of chronic UMTS-modulated radiofrequency exposure in an ethylnitrosourea mouse model. Int J Radiat Biol (2010) 86:529-41. doi:10.3109/09553001003734501 
37. Lerchl A, Klose M, Grote K, Wilhelm AF, Spathmann O, Fiedler T, et al. Tumor promotion by exposure to radiofrequency electromagnetic fields below exposure limits for humans. Biochem Biophys Res Commun (2015) 459:585-90. doi:10.1016/j.bbrc.2015.02.151

38. Bartsch H, Bartsch C, Seebald E, Deerberg F, Dietz K, Vollrath L, et al. Chronic exposure to a GSM-like signal (mobile phone) does not stimulate the development of DMBA-induced mammary tumors in rats: results of three consecutive studies. Radiat Res (2002) 157(2):183-90. doi:10.1667/0033-7587 (2002)157[0183:CETAGL]2.0.CO;2

39. Huang TQ, Lee JS, Kim TH, Pack JK, Jang JJ, Seo JS. Effect of radiofrequency radiation exposure on mouse skin tumorigenesis initiated by 7,12-dimethybenz[alpha]anthracene. Int J Radiat Biol (2005) 81:861-7. doi:10.1080/09553000600568093

40. Heikkinen P, Ernst H, Huuskonen $H$, Komulainen $H$, Kumlin $T$, Mäki-Paakkanen J, et al. No effects of radiofrequency radiation on 3-chloro-4-(dichloromethyl)-5-hydroxy-2(5H)-furanone-induced tumorigenesis in female Wistar rats. Radiat Res (2006) 166:397-408. doi:10.1667/ RR3588.1

41. Yu D, Shen Y, Kuster N, Fu Y, Chiang H. Effects of 900 MHz GSM wireless communication signals on DMBA-induced mammary tumors in rats. Radiat Res (2006) 165:174-80. doi:10.1667/RR3497.1

42. Hruby R, Neubauer G, Kuster N, Frauscher M. Study on potential effects of "902-MHz GSM-type Wireless Communication Signals" on DMBA-induced mammary tumours in Sprague-Dawley rats. Mutat Res (2008) 649:34-44. doi:10.1016/j.mrgentox.2007.07.016

43. Radzievsky AA, Gordiienko OV, Szabo I, Alekseev SI, Ziskin MC. Millimeter wave-induced suppression of B16 F10 melanoma growth in mice: involvement of endogenous opioids. Bioelectromagnetics (2004) 25:466-73. doi:10.1002/ bem. 20018

44. Logani MK, Bhanushali A, Anga A, Majmundar A, Szabo I, Ziskin MC. Combined millimeter wave and cyclophosphamide therapy of an experimental murine melanoma. Bioelectromagnetics (2004) 25:516-23. doi:10.1002/ bem. 20026

45. Logani MK, Szabo I, Makar V, Bhanushali A, Alekseev S, Ziskin MC. Effect of millimeter wave irradiation on tumor metastasis. Bioelectromagnetics (2006) 27:258-64. doi:10.1002/bem.20208

46. Slikker W III, Mei N, Chen T. N-ethyl-N-nitrosourea (ENU) increased brain mutations in prenatal and neonatal mice but not in the adults. Toxicol Sci (2004) 8:112-20. doi:10.1093/toxsci/kfh177

47. Wyde M, Cesta M, Blystone C, Elmore S, Foster P, Hooth M, et al. Report of partial findings from the National Toxicology Program Carcinogenesis Studies of cell phone radiofrequency radiation in Hsd: Sprague Dawley SD rats (whole body exposures). bioRxiv (2016) 1-87. doi:10.1101/ 055699

48. Jin YB, Lee HJ, Seon Lee J, Pack JK, Kim N, Lee YS. One-year, simultaneous combined exposure of CDMA and WCDMA radiofrequency electromagnetic fields to rats. Int J Radiat Biol (2011) 87:416-23. doi:10.3109/09553002. 2010.537428

49. Lee HJ, Jin YB, Lee JS, Choi SY, Kim TH, Pack JK, et al. Lymphoma development of simultaneously combined exposure to two radiofrequency signals in AKR/J mice. Bioelectromagnetics (2011) 32:485-92. doi:10.1002/ bem. 20655

50. Lee HJ, Lee JS, Pack JK, Choi HD, Kim N, Kim SH, et al. Lack of teratogenicity after combined exposure of pregnant mice to CDMA and WCDMA radiofrequency electromagnetic fields. Radiat Res (2009) 172:648-52. doi:10.1667/ RR1771.1

51. Lee HJ, Jin YB, Kim TH, Pack JK, Kim N, Choi HD, et al. The effects of simultaneous combined exposure to CDMA and WCDMA electromagnetic fields on rat testicular function. Bioelectromagnetics (2012) 33:356-64. doi:10.1002/bem.20715

52. Jin YB, Pyun BJ, Jin H, Choi HD, Pack JK, Kim N, et al. Effects of simultaneous combined exposure to CDMA and WCDMA electromagnetic field on immune functions in rats. Int J Radiat Biol (2012) 88:814-21. doi:10.3109/09 553002.2012 .711501
53. Jin YB, Choi HD, Kim BC, Pack JK, Kim N, Lee YS. Effects of simultaneous combined exposure to CDMA and WCDMA electromagnetic fields on serum hormone levels in rats. J Radiat Res (2103) 54:430-7. doi:10.1093/jrr/rrs120

54. López-Furelos A, Miñana-Maiques MM, Leiro JM, Rodríguez-Gonzalez JA, Ares-Pena FJ, López-Martin E. An experimental multi-frequency system for studying dosimetry and acute effects on cell and nuclear morphology in rat tissues. PIER (2012) 29:541-58. doi:10.2528/PIER12042707

55. López-Furelos A, Leiro-Vidal JM, Salas-Sánchez AÁ, Ares-Pena FJ, López-Martín ME. Evidence of cellular stress and caspase-3 resulting from a combined two-frequency signal in the cerebrum and cerebellum of spraguedawley rats. Oncotarget (2016) 7:64674-89. doi:10.18632/oncotarget.11753

56. ICNIRP. Guidelines for limiting exposure to time-varying electric, magnetic and electromagnetic fields (up to $300 \mathrm{GHz}$ ). International Commission on Non-Ionizing Radiation Protection. Health Phys (1998) 74:494-522.

57. Sienkiewicz Z, van Rongen E, Croft R, Ziegelberger G, Veyret B. A closer look at the thresholds of thermal damage: workshop report by an ICNIRP Task Group. Health Phys (2016) 111:300-6. doi:10.1097/HP.0000000000000539

58. Dewhirst MW, Lora-Michiels M, Viglianti BL, Dewey WC, Repacholi M. Carcinogenic effects of hyperthermia. Int J Hyperthermia (2003) 19:236-51. doi:10.1080/0265673031000070811

59. Juutilainen J, Höytö A, Kumlin T, Naarala J. Review of possible modulationdependent biological effects of radiofrequency fields. Bioelectromagnetics (2011) 32:511-34. doi:10.1002/bem.20652

60. BioIniative Report. A Rationale for a Biologically-Based Public Exposure Standard for Electromagnetic Fields. (2012). Available from: http://www. bioinitiative.org

61. Challis LJ. Mechanisms for interaction between RF fields and biological tissue. Bioelectromagnetics (2007) (Suppl 7):S98-106. doi:10.1002/bem.20119

62. Apollonio F, Liberti M, Paffi A, Merla C, Marracino P, Denzi A, et al. Feasibility for microwaves energy to affect biological systems via nonthermal mechanisms: a systematic approach. IEEE Trans Microw Theory Tech (2013) 61:2031-45. doi:10.1109/TMTT.2013.2250298

63. Sheppard AR, Swicord ML, Balzano Q. Quantitative evaluations of mechanisms of radiofrequency interactions with biological molecules and processes. Health Phys (2008) 95:365-96. doi:10.1097/01.HP.0000319903. 20660.37

64. Kowalczuk C, Yarwood G, Blackwell R, Priestner M, Sienkiewicz Z, Bouffler S, et al. Absence of nonlinear responses in cells and tissues exposed to RF energy at mobile phone frequencies using a doubly resonant cavity. Bioelectromagnetics (2010) 31:556-65. doi:10.1002/bem.20597

65. IEEE. IEEE Standard for Safety Levels with Respect to Human Exposure to Radio Frequency Electromagnetic Fields, $3 \mathrm{kHz}$ to $300 \mathrm{GHz}$. Institute of Electrical and Electronics Engineers, IEEE Std C95.1. New York: IEEE (2005).

66. Leszczynski D. Effects of radiofrequency-modulated electromagnetic fields on proteome. Adv Exp Med Biol (2013) 990:101-6. doi:10.1007/97894-007-5896-4_6

67. Rivina L, Davoren MJ, Schiestl RH. Mouse models for radiation-induced cancers. Mutagenesis (2016) 31:491-509. doi:10.1093/mutage/gew019

68. Rangarajan A, Weinberg RA. Opinion: comparative biology of mouse versus human cells: modelling human cancer in mice. Nat Rev Cancer (2003) 3:952-9. doi:10.1038/nrc1235

Conflict of Interest Statement: The authors declare that this work was conducted in the absence of any commercial or financial relationships that could be constructed as a potential conflict of interest, except Sienkiewicz declares that he has owned 440 ordinary shares in BT Group, a communication services company.

Copyright (๑) 2017 Sienkiewicz, Calderón, Broom, Addison, Gavard, Lundberg and Maslanyj. This is an open-access article distributed under the terms of the Creative Commons Attribution License (CC BY). The use, distribution or reproduction in other forums is permitted, provided the original author(s) or licensor are credited and that the original publication in this journal is cited, in accordance with accepted academic practice. No use, distribution or reproduction is permitted which does not comply with these terms. 